Research Article

\title{
Director Networks and Cost of Equity Capital: Based on "Busy Director Hypothesis" Analysis
}

\author{
Sai Qiu (iD) ${ }^{1}$ and Xin Sun (iD) ${ }^{2}$ \\ ${ }^{1}$ School of Accounting, Shandong University of Finance and Economics, Jinan 250014, China \\ ${ }^{2}$ School of Business Administration, Shandong University of Finance and Economics, Jinan 250014, China \\ Correspondence should be addressed to Sai Qiu; 445653945@qq.com
}

Received 7 September 2021; Accepted 9 October 2021; Published 16 October 2021

Academic Editor: Daqing Gong

Copyright ( $(2021$ Sai Qiu and Xin Sun. This is an open access article distributed under the Creative Commons Attribution License, which permits unrestricted use, distribution, and reproduction in any medium, provided the original work is properly cited.

This paper uses the data of Shanghai and Shenzhen A-share-listed companies from 2008 to 2018 to construct the director networks as an indicator to explore the relationship between the company's director networks and the cost of equity capital and the influence of nature of property rights and the ownership structure on the aforementioned relationship. The research results demonstrate that director networks cannot effectively reduce the cost of equity capital. This conclusion verifies the "busy director hypothesis." With the increase in the director networks centrality, the increase in the cost of equity capital in non-state-owned listed companies is more significant compared with state-owned listed companies; equity concentration plays a significant negative regulatory role in the director networks centrality and affects the cost of equity capital. Compared with the networks centrality of independent director, the networks centrality of nonindependent director has a stronger negative effect on the cost of equity capital. This article broadens the perspective of corporate governance research and provides new ideas for listed companies to make financing decisions.

\section{Introduction}

As a hot topic of corporate governance research in recent years, board governance plays an important role in the sustainable development of companies. The most fundamental reason for the existence of the board of directors is tantamount to solve the common principal-agent problem in the company. The oversight function should be the most essential function of the board. Previous studies on the board of directors tend to be concentrated on two aspects: on one hand, it is the attribute of the board of directors. The attributes of the board of directors here include the composition, size, personal characteristics, and leadership structure of the board [1]. Second, the influence of the responsibilities of the board of directors on corporate governance [2]. In recent years, with the wide application of social network analysis methods and the widespread phenomenon of the chain of directors in enterprises, the academic circle has gradually begun to study the influence of the director networks generated by the concurrent relationship of directors on corporate governance. In 2008, listed companies with interlocking directors accounted for more than $85 \%$ of all listed companies in China. By 2010, that share had increased to more than $90 \%$. It can be said that the director networks have become a common phenomenon in China's listed companies and has attracted extensive attention from academia and business circles. The director networks can not only form the enterprise association that plays an important role in the development of the company [3] but also affect the function and mechanism of the board of directors, thus enhancing the ability of the enterprise to obtain information and alleviating the constraint of scarce resources [4]. Brown et al. [5] found that the relationship between directors increased their contribution to the consulting of the company. At the same time, research by Bianchi et al. [6] has begun to realize that multiple directorate positions are conducive to obtaining information and resources, but also lead to the busyness of directors. The "busy interlocking director," the rent-seeking behavior of interlocking directors and the "insider" control behavior of the board of directors may 
affect the independence of directors and weaken the supervision function of directors to some extent.

Since 2017, the acceleration of China's A-share-approved IPO has led to the issuance of new shares taking on more normalized and market-oriented characteristics. This provides companies with more equity financing channels. As an important reference index of whether a company carries out equity financing, the cost of equity capital has an essential impact on the capital flow and resource allocation of the entire capital market. There is the absence of research on how different corporate governance mechanisms (CGMs) affect the cost of equity capital [7, 8]. Chen et al. [9] found that companies with strong shareholder rights have much lower implied cost of equity and that the impact of shareholder rights on reducing cost of equity causes more serious agency problems for free cash flow, which is significantly stronger. Pham et al. [10] suggest that when directors and owners borrow excessively to accumulate wealth, the firm will bear a higher cost of equity capital. The existing literature mainly studies the influence of corporate governance mechanism on the cost of capital. It is of great practical significance to explore the influence of the director networks on the cost of equity capital. The existing research on the director networks can be divided into two aspects. On one hand, the influence of the director networks on the behaviors of the two companies is considered. The consistency of accounting policies and the convergence of M\&A decisionmaking behavior is often mentioned. On the other hand, it discusses the impact of the position of a company in the director networks and the position (centrality) of interlocking directors in the director networks on corporate behavior and performance. The effect of director networks on the company's income quality [11], initial public offering [12], and enterprise performance $[13,14]$, stock price crash risk [15], the capital structure [16], accounting practice [17], and the enterprise investment [18] is often involved. Previous literature has paid less attention to the relationship between director networks and corporate financing. Owing to the limited time and energy of interlocking directors, the supervision ability of interlocking directors is a scarce resource. The same director serving in multiple companies requires a reallocation of limited resources. Failure to improve the supervision efficiency caused by resource reconfiguration will affect the operational efficiency and the quality of corporate governance to a certain extent. Therefore, whether the high director networks centrality can influence the operational efficiency and quality of corporate governance through the "director busyness effect" and thus exert an influence on the financing of enterprises is worth further discussion.

The ownership structure determines the composition and decision-making of the shareholders' congress and plays a major role in the structure and system of the board of directors. Then can different ownership structures have an impact on the relationship between director networks and cost of equity capital? In addition, is the relationship between director networks and cost of equity capital affected by the nature of property rights? Will the director networks relationship between independent directors and nonindependent directors have a differentiated impact on the cost of equity capital of a company? This paper intends to use the data of A-share-listed companies in China's Shanghai and Shenzhen stock exchanges from 2008 to 2018 to construct director networks whose network nodes are listed companies and whose network links are concurrent directors and to reflect the position of interlinked directors in the director networks through the index of director networks centrality. On this basis, this paper conducts the following studies: first, it discusses the direct impact of network centrality on the cost of equity capital for listed companies. In addition, this paper discusses the influence of property right nature on the relationship between director networks and cost of equity capital and introduces the index of equity concentration to study the influence of the director networks on cost of equity capital under different ownership structure. This paper further discusses the impact of the network of independent directors and nonindependent directors on the cost of equity capital. The research of this paper provides a reasonable basis for optimizing the structure of director networks and reducing the cost of equity capital of Chinese listed companies.

The main contributions of this paper are presented in four aspects. First, from the perspective of social network analysis, this paper discusses the influence mechanism of the director networks on the cost of equity capital and studies the impact of equity concentration on the relationship between the director networks and the cost of equity capital. This is not very common in contemporary studies. This study can enrich the literature in the field of interlocking directors. Second, from the perspective of enterprise owners, this paper understands the relationship among the nature of ownership, director networks, and cost of equity capital and provides a theoretical basis and practical reference for different types of enterprises to select directors in line with their strategic development. Third, this paper distinguishes two types of directors, independent director and nonindependent director, and analyzes the difference of the influence of different types of directors on the performance of duties. This contributes to better understand the relationship between director governance and economic consequences. Fourth, most previous studies have affirmed the positive effects of the director networks, but few have mentioned its negative effects. This paper explores the negative effects of director networks.

The rest of the study is as follows: Section 2 is a literature review and corresponding research hypotheses. Section 3 is the data source and research design. This part introduces the data source, variable definition, and models used in this research. Section 4 is the test of the influence of the director network on the cost of capital and its moderating effect. Section 5 is the robustness test. Section 6 is the research conclusion and policy recommendations.

\section{Literature Review and Research Hypothesis}

2.1. Director Networks and Cost of Equity Capital. Many directors in the network tend to be keen on informal activities such as golf clubs, charity events, and media events. 
These occasions (activities) need to consume a lot of time and energy of chain directors, so that they do not have sufficient time and energy to play their roles. The potential problem faced by chain directors in multiple companies at the same time is that they do not have sufficient time and energy to perform their duties as directors. A great deal of work cannot be done with quality and quantity without time and energy as the basic guarantee. The energy and time spent by directors in other interlocking companies will be greatly reduced or shortened by their energy and time in full-time companies. Huang et al. [19] found that companies that receive more attention from directors are associated with lower cost of equity, and these companies also have a higher quality of accounting information. Barhava et al. [20] studied the impact of the resignation of multiseat independent directors on the stock prices of other companies they held concurrent posts and found that the resignation of multiseat independent directors in a company would lead to a significant increase in the stock prices of other companies they held concurrent posts. The author's explanation for this conclusion is that the resignation of multiple independent directors from one company can allocate more of their time and energy to other companies. Masulis and Zhang [21] proved that companies with distracted directors are related to the decline of corporate value and business performance.

The increased time and energy that directors spend on corporate governance will have a positive impact on the decision-making and supervision of corporate operations and corporate performance. Ferris et al. [22] first proposed the "busy director hypothesis." Directors who only work for one company can devote all their time and energy to that company and be better able to carry out their functions. Directors serving in several companies can result in a reallocation of time and energy. This makes it impossible for interlocking directors to work seriously in an enterprise, thus increasing the agency cost of the enterprise. Other scholars have further tested the "busy director hypothesis." Fich and Shivdasani [23] found through research that the supervision efficiency of independent directors working in three or more companies would be significantly reduced. Hsu and Li [24] believe that chain directors cannot effectively supervise the management due to the multitude of affairs, thus leading to agency problems. Director networks formed by interlocking directors increase the agency cost between shareholders and management, which also affect the improvement of corporate performance to a certain extent. Santos and Silveira [25] took 350 Brazilian enterprises as research samples and found that the busy work tasks of chain directors would lead to the deterioration of their decision-making quality, which would have an impact on corporate performance. Non and Franses [26] took Dutch enterprises as research samples and found that the increase in the number of interlocking directors did not conducive to the improvement of the company's future performance. The number of interlocking directors in a company is negatively correlated with corporate performance. In addition, those interlocking directors who hold a large number of concurrent positions often take the initiative to spend more time and energy on work or activities outside the company, which has a negative influence on the improvement of corporate governance level. The reason is the fact that they hope to use these activities outside the company to further consolidate or enhance their human capital and obtain more director subsidies and other nonmonetary benefits.

In the process of financing, good corporate governance can often effectively weaken the degree of investors' adverse selection and thus reduce the cost of equity financing. Jiang and $\mathrm{Lu}$ [27] found that effective corporate governance mechanism can weaken the degree of information asymmetry and alleviate the efficiency of resource allocation in the market, thus reducing the cost of equity financing of enterprises. Alhares [28] discussed a strong and significant negative correlation between good corporate governance and equity financing costs. Iskander and Chamlou [29] found through research that good corporate governance level plays an important role in improving investor confidence and enhancing enterprises' equity financing ability. Cheng et al. [30] discussed that a more effective board of directors would decrease the cost of equity capital of an enterprise from the perspective of the board of directors. This paper argues that the phenomenon of concurrent directors will lead to the corresponding "director busyness." As an important part of the modern corporate governance structure, directors cannot effectively supervise enterprises when they are busy, which leads to the decline of the corporate governance level. It is not conducive to the reduction of the cost of equity capital.

Hypothesis 1. There is a significant positive correlation between the director networks centrality and the cost of equity capital.

\subsection{Director Networks, Nature of Property Rights, and Cost of} Equity Capital. Different property rights, especially the listed companies with state-owned background, can affect the performance of corporate governance. First of all, the will and interests of the government often influence the behavior of state-owned enterprises. Compared with private enterprises, state-owned enterprises are more susceptible to government intervention and attract supervision from the public, media, and Party organizations. The subjective initiative of chain directors in state-owned enterprises is stronger than that in private enterprises. The independence of the independent directors that appointed by the superior authorities of state-owned listed companies can be effectively guaranteed so that they can better play their supervisory role. Influenced by "cadres under party management," the Party committee enters the enterprise and holds "crossoffice" with the board of directors, which will form a more effective supervisory mechanism and promote the chain directors to play a better supervisory role. Masulis and Zhang [21] believed that the phenomenon of "cross-entry and cross-appointment" between the Party committee and the board of directors of state-owned enterprises would weaken the independence of the board of directors. Wu et al. [31] found in their research that major decisions of state- 
owned enterprises can be implemented with the approval of higher authorities. The directors of state-owned enterprises play a very minor role in the strategic decision-making process, so the board capital usually does not play a substantial role. Private enterprise environment and market operation mechanism can make the board of directors play its role more effectively. The greater power of the board of directors promotes the interlocking directors to obtain more effective information and resources from the director networks and provides conditions for the opportunistic behavior of them.

Strong administrative color of state-owned enterprises makes the post of director concurrently usually contain administrative characteristics. The experience of directors of state-owned enterprises labeled as "quasi-officials" is conducive to the realization of directors" own "political demands" and provides possibilities for the expansion of future career channels. The personnel information preservation system within the government and the multichannel transmission mode will form a certain deterrent effect on the behavior of directors of state-owned enterprises. While performing their functions, concurrent directors shall take full account of the information files stored in the system to reduce or avoid the adverse impact on their entire career caused by improper supervisory behavior. Managers of state-owned enterprises are more concerned with their own political future.

The sustainable development of state-owned enterprises is of vital importance to the stability and development of the economy. Owing to their particularity, state-owned enterprises can often enjoy more preferential policies and risk guarantees provided by the government. Compared with private enterprises, state-owned enterprises usually have lower investment risk and higher enterprise value. The necessary rate of return required by investors to take risk into account, that is, cost of equity capital of state-owned enterprises will be lower. Wei et al. [32] considered that government benefits, such as financial subsidies, tax exemptions, lower market access conditions, and the risk guarantee of government reputation that state-owned enterprises can obtain from the government will eventually lead to lower cost of equity capital. This paper argues that the relationship between the director networks and the cost of equity capital is affected by the nature of property rights. Chain directors of state-owned enterprises are more vulnerable to scrutiny because the public, party organizations, and other government departments pay more attention to state-owned enterprises. In addition, chain directors of state-owned enterprises are more interested in their future prospects.

Hypothesis 2. Compared with state-owned listed companies, director networks of non-state-owned listed companies have a more significant negative impact on the cost of equity capital.

2.3. Director Networks, Equity Concentration, and Cost of Equity Capital. As the basis of the property right of the corporate governance system, the ownership structure determines the composition and operation mode of the shareholders' meeting and then affects the structure and decision-making of the board of directors. From the perspective of the influence mechanism of ownership structure, on one hand, equity concentration itself can be invoked as a corporate governance mechanism [33]. The ownership structure with a high degree of concentration represents that the major shareholders have absolute control over the company and have the motivation to directly participate in the operation and supervision of the company. In addition, compared with scattered minority shareholders, the high professional level and skills of major shareholders and various institutional investors make it more convenient for them to perform the effective supervision function of shareholders and the supervision cost is relatively less. On the other hand, the ownership structure with extreme concentration can solve the regulatory "free rider" phenomenon caused by excessive decentralization of ownership to a certain extent. That is, minority shareholders do not get the right to speak in corporate governance due to their low shareholding ratio and relatively dispersed shareholding. Due to the inconsistency of interests among the minority shareholders, it is difficult to reach a unanimous decision, which leads to the lack of motivation for them to supervise and serve as directors concurrently. At this time, the small shareholders are more inclined to "free ride" or even have nothing to do with it, which leads to the failure of shareholders to exert their supervisory function on the interlocking directors. In the case of relatively dispersed corporate ownership, directors have a stronger supervisory effect on managers than shareholders directly supervise the managers [34]. On the contrary, the controlling shareholders and the small and medium shareholders will produce the convergent effect of interests as the company's equity is increasingly concentrated. The interest towards consistency makes the minority shareholders enhance the motivation of supervising and serving as directors and alleviates the "free rider" problem. The motivation and ability of direct supervision by major shareholders and medium and small shareholders will replace director supervision to some extent. The weakening of demand and dependence of director supervision makes the director's supervision function weaken. Built on the support effect of major shareholders, this paper believes that major shareholders with high equity concentration have a stronger supervision effect on the management and can effectively alleviate the problem of regulatory confusion. Zhou [35] believes that the financing cost of an enterprise will rise first and then fall with the increasing shareholding ratio of the largest shareholder. Appropriate equity concentration can alleviate the absence of supervision.

The improvement of equity concentration is conducive to strengthening the supervision of shareholders on interlocking directors and restraining the opportunistic behavior of interlocking directors which lead to the use of the director networks to seek personal interests. The mutual benefit synergy between major shareholders and other small and medium-sized shareholders urges interlocking directors to use the interlocking director networks to "hollow out" the 
company, which will be subject to the restraint and supervision of different shareholders. The motivation and willingness of shareholders to supervise the management will increase with the increase in equity concentration. The moderate equity concentration or the alliance of a few major shareholders can effectively restrain the management from seeking subjective interests using multiple information sources and information dissemination channels of the director networks, thus helping to reduce the agency cost of the enterprise. In addition, the improvement of corporate equity concentration can effectively reduce the agency problem between major shareholders and management and promote the effective improvement of corporate governance efficiency [36]. On one hand, this paper believes that the equity concentration to a certain extent will alleviate the "free rider" behavior of minority shareholders. On the other hand, this paper holds that the major shareholders have more motivation to supervise the concurrent directors because they enjoy absolute control rights. The relationship between director networks and cost of equity capital is influenced by equity concentration.

Hypothesis 3. There is an interaction between equity concentration and the impact of director networks on the cost of equity capital, and equity concentration weakens the negative impact of director networks on the cost of equity capital.

\section{Data Source and Research Design}

3.1. Data Source. In this paper, A-share companies listed on the Shanghai and Shenzhen stock exchanges from 2008 to 2018 were selected as the initial samples and screened according to the following criteria: (1) samples from the financial and insurance industries were excluded. (2) Samples that have suffered losses for three consecutive years and have been warned of delisting risks were excluded. (3) Samples that have suffered losses for two consecutive years and have been specially treated were excluded. (4) The abnormal samples of the cost of equity capital should be removed (the value of the cost of equity capital should be between 0 and 1 and outside this region as the outlier). (5) Samples with missing values of required variables were removed. (6) Samples with extreme values of variables were removed. In the end, 5,900 sample observations were generated. This paper calculates the data of director networks centrality through the following steps: first, Excel is used to summarize and process the original data of board composition in the sample. Second, to ensure that the information of directors is not repeated, this paper checks the personal information of directors including age, education, and work experience, and eliminates the data of directors with the same name whose statistical information is different. In this paper, the company-director sequence of all A-share-listed companies in Shanghai and Shenzhen Stock Exchange from 2008 to 2018 is obtained. Third, the two-mode companydirector networks matrix is converted into one-mode company network matrix after the sequence is substituted into Pajek software, and the director networks
centrality-Degree centrality and Betweenness centrality is calculated by UCINET6.0 software. The original data of board composition and financial data in this paper are from CSMAR database. In this paper, software such as Eviews7.0, Pajek, and UCINET 6.0 is used to process and analyze the data. The variables are detailed in Table 1.

\subsection{Variable Definition}

3.2.1. Measurement of Cost of Equity Capital. In academic circles, there are two estimation models for the explained variable cost of equity capital: ex-post cost of equity capital and ex-ante cost of equity capital. Drawing on the research of Easton [37], this paper selects the ex-ante cost of equity capital model-PEG model to estimate the cost of equity capital. The calculation formula is as follows:

$$
\mathrm{RE}=\sqrt{\frac{\left(e p s_{i, t+2}-e p s_{i, t+1}\right)}{P_{\mathrm{it}}} .}
$$

In the aforementioned formula, $\mathrm{RE}_{\mathrm{it}}$ is the cost of equity capital of company $I$ in $t$ year calculated by PEG model. $P_{\mathrm{it}}$ is the closing stock price of company $I$ at the end of $t$ year. $e p s_{i, t+1}$ represents the earnings per share predicted by analysts for $t+1$ year. eps $s_{i, t+2}$ represents the earnings per share predicted by analysts for $t+2$ year.

3.2.2. Measurement of Director Networks. The explanatory variable director networks centrality is the degree to which the same director holds a concurrent post in different companies. The director networks centrality includes the number of companies in which the same director holds an interlocking position and the degree to which internal or external interlocking directorships connect different companies. According to the research of Freeman [38], this paper selects two indexes, Degree centrality and Betweenness centrality, to measure the director networks centrality.

(1) Degree centrality refers to the number of direct connections between target directors and other directors of the director networks. This indicator reflects the target director's ability to interact directly with other directors. The calculation formula is as follows:

$$
\text { Degree }_{i}=\frac{\sum_{j} X_{j i}}{(g-1)}
$$

where $i$ represents the target director, $j$ represents directors other than the target director, $X_{j i}$ means that the two parties form a direct connection, and $G$ is the total number of directors in the director networks. The formula is divided by $g-1$ to eliminate the effect of network size.

(2) Betweenness centrality represents the degree to which the target director is between any two other directors in the director networks. This indicator reflects the intermediary position of the target director in the director networks. The calculation formula is as follows: 
TABLE 1: Variable definitions.

\begin{tabular}{|c|c|c|}
\hline Symbol & Variable name & Variable definition \\
\hline $\mathrm{RE}$ & The cost of capital & PEG model \\
\hline Degree & Degree center & $\begin{array}{c}\text { The number of direct connections between target directors and other directors in the director } \\
\text { networks }\end{array}$ \\
\hline Betweenness & Betweenness centrality & The degree to which an individual lies between any two other individuals in a network \\
\hline Top1 & $\begin{array}{l}\text { Degree of equity } \\
\text { concentration }\end{array}$ & The shareholding ratio of the largest shareholder \\
\hline State & Property rights & Nature of ultimate controller: 1 in case of state-owned holding, 0 otherwise \\
\hline It & Inventory turnover & Main business cost/average inventory balance \\
\hline Roe & Return on net assets & Net income/average balance of owners' equity \\
\hline Grow & Growth rate of revenue & $\begin{array}{c}\text { (Operating income for the current period-operating income for the same period of the previous } \\
\text { year)/operating income for the same period of the previous year }\end{array}$ \\
\hline Tat & Total asset turnover & Operating revenue/average total assets \\
\hline Lev & Financial leverage & Long-term borrowings/total assets \\
\hline Lnpe & Stock price/earnings ratio & The natural logarithm of the average annual price/earnings ratio of individual stocks \\
\hline $\mathrm{R} \& \mathrm{D}$ & $\begin{array}{c}\mathrm{R} \& \mathrm{D} \text { investment } \\
\text { intensity }\end{array}$ & Ratio of R\&D investment to revenue \\
\hline Dual & Dual & 1 when the chairman is concurrently the general manager, 0 otherwise \\
\hline Year & Year & Control for year-fixed effect \\
\hline Industry & Industry & Control for industry-fixed effect \\
\hline
\end{tabular}

$$
\text { Betweenness }_{\mathrm{i}}=\frac{\left(\sum_{j<k} g_{j k\left(n_{i}\right)} / g_{j k}\right)}{[(g-1)(g-1) / 2]},
$$

where $g_{j k}$ represents the number of shortcuts to be passed between director $j$ and director $k \cdot g_{j k(n i)}$ represents the number of director $i$ in the shortcut connecting director $j$ to director $k$. The formula is divided by $(g-1)(g-2)$ to eliminate the effect of the size of the directors.

3.2.3. Measurement of Nature of Property Rights. After eliminating the listed companies whose controlling shareholders are not recognized, this paper defines the stateowned holding company as the state-owned listed company with the value of State at 1 . The remaining privately owned and foreign-owned companies are defined as non-stateowned listed companies, and the value of State is 0 .

3.2.4. Measurement of Control Variables. In this paper, we refer to the research of Zhang et al. [39] and add the following control variables: inventory turnover (It), return on net assets (Roe), growth rate of operating income (Grow), total asset turnover (Tat), financial leverage (Lev), stock price/earnings ratio (Lnpe), dual (Dual), and $R \& D$ investment $(\mathrm{R} \& \mathrm{D})$. All variable designs are shown in Table 1.

3.3. Model Design. Model 1 (2) is adopted in this paper to test Hypothesis 1 (2):

$$
\mathrm{RE}=\beta_{0}+\beta_{1} \text { Net-cen }+\beta_{2} \mathrm{It}+\beta_{3} \text { Roe }+\beta_{4} \text { Grow }+\beta_{5} \text { Tat }+\beta_{6} \text { Lev }+\beta_{7} \text { Lnpe }+\beta_{8} \text { R\&D }+\beta_{9} \text { Dual }+\sum \text { Year }+\varepsilon
$$

Model 1. This paper uses Model 1 to verify the effect of director networks centrality on the cost of equity capital. The explained variable is the cost of equity capital of the listed company (RE). The explanatory variable is Net-cen, which includes Degree centrality and Betweenness centrality. The control variables include inventory turnover (It), return on net assets (Roe), growth rate of operating income (Grow), total asset turnover (Tat), financial leverage (Lev), stock price/earnings ratio (Lnpe), Dual (Dual), and R\&D investment $(\mathrm{R} \& \mathrm{D})$.

In this paper, the full sample is divided into state-owned listed companies and non-state-owned listed companies according to the nature of property rights, and Model 2 is used to test the relationship between the director networks centrality and the cost of equity capital of enterprises with different property rights.

Model 3 is adopted in this paper to test Hypothesis 3:

$$
\begin{aligned}
\mathrm{RE}= & \beta_{0}+\beta_{1} \text { Net }- \text { cen }+\beta_{2} \text { Top } 1+\beta_{3} \text { Net }- \text { cen } * \text { Top } 1+\beta_{4} \mathrm{It}+\beta_{5} \text { Roe }+\beta_{6} \text { Grow }+\beta_{7} \text { Tat }+\beta_{8} \text { Lev }+\beta_{9} \text { Lnpe }+\beta_{10} \text { R } \& D \\
& +\beta_{11} \text { Dual }+\sum \text { Year }+\varepsilon .
\end{aligned}
$$


Model 3. In Model 3, an interaction term between director networks location and equity concentration (Netcen $*$ Top 1 ) was added to test the moderating effect of equity concentration on the relationship between director networks centrality and cost of equity capital.

\section{Empirical Test}

4.1. Results of Univariate Difference Analysis. In this paper, the total samples obtained were classified according to the property right nature, and the $t$-test method and Mann-Whitney nonparametric test method were used to test whether there were significant differences between stateowned listed companies and non-state-owned listed companies in various variables. The results are shown in Table 2.

Table 2 demonstrates that the number of non-stateowned listed companies accounts for $2 / 3$ of the total sample number. From 2008 to 2018, the average cost of equity capital of state-owned listed companies and non-stateowned listed companies is 0.1007 and 0.0873 , respectively, and the difference is obvious. This result shows that the cost of equity capital of listed companies with different property rights is quite different. The mean of degree centrality $(0.0327)$ and the mean of betweenness centrality $(0.1277)$ of state-owned listed companies were slightly higher than the mean of non-state-owned listed companies. The large difference between the mean and median of the network centrality of the two types of companies indicates that the director networks centrality of the state-owned listed companies is greater. This paper can preliminary judge that there are some differences in the cost of equity capital and the director networks centrality between the two types of companies.

In terms of ownership structure, the mean shareholding ratio of the largest shareholder in the two groups of samples was 39.9802 and 33.0899, respectively, and the median difference of equity concentration was obvious. The equity concentration of state-owned listed companies is higher. The result is shown that only a very few state-owned listed companies have the same chairman and general manager. The situation of chairman concurrently serving as general manager is more prevalent in non-state-owned listed companies, and the average value reaches $36.95 \%$. Inventory turnover, return on net assets, growth rate of operating income, turnover of total assets, financial leverage, stock price/earnings ratio, intensity of R\&D investment, and other indicators of the two groups of samples all passed the $t$-test of mean difference and the nonparametric test of median difference. The average value of $R \& D$ investment of stateowned listed companies (3.1113) is less than that of nonstate-owned listed companies (4.9740), which indicates that non-state-owned listed companies prefer R\&D expenditure.

4.2. Correlation Analysis. We performed Pearson's test and Spearman's test on the sample data to better consider the correlation between the selected variables. Table 3 lists the Person's correlation coefficient and the Spearman correlation coefficient matrix of each variable in the regression model. As can be seen from the correlation table, the cost of equity capital (RE) is significantly positively correlated with degree centrality and betweenness centrality in the univariate case. The cost of equity capital (RE) is positively correlated with the rate of return on net assets (Roe), total asset turnover (Tat), and financial leverage (Lev) in the univariate case, and it is significant at the $1 \%$ level. The cost of equity capital (RE) is negatively correlated with the price/ earnings ratio (Inpe), R\&D investment intensity (R\&D), and dual job (Dual) in the univariate case, and it is also significant at the $1 \%$ level. The coefficients in Table 3 describe the general correlation between variables, so that the specific relationship between them can only be further obtained by regression analysis.

4.3. Director Networks and Cost of Equity Capital. In this paper, OLS multiple regression method is used to empirically test the samples to investigate the impact of director networks centrality on the cost of equity capital of listed companies. The results are presented in Table 4.

Columns 1, 2, and 3 in Table 4 represent the effect of degree centrality on cost of equity capital under the action of different control variables. Columns 4, 5, and 6 represent the effect of betweenness centrality on the cost of equity capital under the action of different control variables. The results demonstrate that the degree centrality is positively correlated with the cost of equity capital and the betweenness centrality is positively correlated with the cost of equity capital under the effects of different control variables. The cost of equity capital of listed companies increases with the increase of the director networks centrality. Hypothesis 1 of this paper is confirmed. This paper explains that interlocking directors, as an important part of modern corporate governance structure, cannot effectively supervise enterprises when they are busy. This phenomenon leads to the decline of the corporate governance level and is not conducive to the reduction of the cost of equity capital. The control variables of stock price/ earnings ratio (Inpe), R\&D investment intensity (R\&D) and dual job (Dual) are significantly negatively correlated with the cost of equity capital. Companies with a high price/earnings ratio, a superior intensity of $R \& D$ investment and a dual role have a lower cost of equity capital. Financial leverage (Lev) is positively correlated with cost of capital. Highly leveraged companies have a higher cost of equity capital. In addition, inventory turnover (It) is negatively correlated with the cost of equity capital, while growth rate of operating income (Grow) is positively correlated with the cost of equity capital, but the relationship between them is not significant.

\subsection{Director Networks, Nature of Property Rights, and Cost of} Equity Capital. It can be found from Table 5 that the degree centrality and the betweenness centrality of state-owned listed companies in columns $1,3,5$, and 7 are not significantly negatively correlated with the cost of equity capital. There is no significant negative correlation between director networks centrality and cost of equity capital in state-owned listed companies. In column 2, 4, 6, and 8, the degree centrality and the betweenness centrality of non-state- 
TABLE 2: Variables in the subsample classified by property right nature.

\begin{tabular}{|c|c|c|c|c|c|c|c|c|}
\hline \multirow{2}{*}{ Variables } & \multicolumn{3}{|c|}{ State-owned listed companies $(N=1984)$} & \multicolumn{3}{|c|}{$\begin{array}{c}\text { Non-state-owned listed companies } \\
(N=3916)\end{array}$} & \multicolumn{2}{|c|}{ Test between groups } \\
\hline & $\begin{array}{l}\text { The } \\
\text { mean }\end{array}$ & $\begin{array}{l}\text { The standard } \\
\text { deviation }\end{array}$ & $\begin{array}{l}\text { The } \\
\text { median }\end{array}$ & The mean & $\begin{array}{c}\text { The standard } \\
\text { deviation }\end{array}$ & $\begin{array}{l}\text { The } \\
\text { median }\end{array}$ & $\begin{array}{l}\text { Mean } \\
\text { difference }\end{array}$ & $\begin{array}{l}\text { Median } \\
\text { difference }\end{array}$ \\
\hline $\mathrm{RE}$ & 0.1007 & 0.0749 & 0.0820 & 0.0873 & 0.0626 & 0.0752 & $0.0133^{* * *}$ & 0.0068 \\
\hline Degree & 0.0327 & 0.0223 & 0.0288 & 0.0257 & 0.0191 & 0.0213 & $0.0070^{* * *}$ & $0.0075^{* * *}$ \\
\hline Betweenness & 0.1277 & 0.1574 & 0.0774 & 0.0905 & 0.1315 & 0.0477 & $0.0373^{* * *}$ & $0.0297^{* * *}$ \\
\hline Top1 & 39.9802 & 14.7777 & 39.3433 & 33.0899 & 13.6906 & 31.3074 & 6.8971 & $8.0359^{* * *}$ \\
\hline It & 15.7378 & 194.5542 & 4.1460 & 119.0146 & 214.2790 & 3.5830 & -103.2768 & $0.5630^{* * *}$ \\
\hline Roe & 0.0877 & 0.2073 & 0.0694 & 0.0898 & 0.0688 & 0.0755 & $-0.0021^{* * *}$ & -0.0061 \\
\hline Grow & 0.2112 & 1.7613 & 0.1011 & 0.4238 & 5.2085 & 0.1680 & $-0.2126^{*}$ & $-0.0669^{* * *}$ \\
\hline Tat & 0.7347 & 0.5195 & 0.6179 & 0.6722 & 0.5088 & 0.5769 & $0.0625^{* *}$ & $0.0410^{* * *}$ \\
\hline Lev & 1.6954 & 2.3449 & 1.1398 & 1.3362 & 2.7105 & 1.0521 & $0.3592^{* * *}$ & $0.0877^{* * *}$ \\
\hline Inpe & 3.7960 & 1.1418 & 3.6033 & 3.9714 & 1.0166 & 3.7970 & $-0.1754^{* *}$ & -0.1937 \\
\hline $\mathrm{R} \& \mathrm{D}$ & 3.1113 & 3.5823 & 2.5800 & 4.9740 & 5.2222 & 3.7400 & $-1.8627^{*}$ & $-1.1600^{* * *}$ \\
\hline Dual & 0.0947 & 0.2929 & 0.0000 & 0.3695 & 0.4827 & 0.0000 & $-0.2748^{* * *}$ & $0.0001^{* * *}$ \\
\hline
\end{tabular}

Note: ${ }^{* * *} p<0.01,{ }^{* *} p<0.05$, and ${ }^{*} p<0.1$.

owned listed companies are significantly positively correlated with the cost of equity capital. The correlation coefficient between director networks centrality and cost of equity capital of non-state-owned listed companies is significantly higher than that of full-sample companies. Compared with state-owned listed companies, director networks of non-state-owned listed companies can increase the cost of equity capital. Hypothesis 2 of this paper is confirmed. This conclusion confirms that the relationship between the director networks and the cost of equity capital is influenced by the nature of property rights. The public, party organizations, and other government functional departments pay greater attention to state-owned listed companies, which makes the concurrent directors of stateowned listed companies easier to be supervised. In addition, interlocking directors of state-owned enterprises pay greater attention to their political promotion opportunities. The influence of the enterprises they work for on their political and professional careers leads them to be willing to invest more time and energy in supervision of the enterprises. This improves the operational efficiency of corporate governance and has a favorable impact on financing decisions, thus leading to a lower cost of equity capital for enterprises.

4.5. Director Networks, Equity Concentration, and Cost of Equity Capital. Columns 1 and 2 in Table 6 represent the influence of diverse equity concentration degrees on the relationship between director networks centrality and cost of equity capital in the full sample. Columns 3 and 4 represent the impact of equity concentration on the relationship between director networks centrality and cost of equity capital of state-owned listed companies. Columns 5 and 6 represent the influence of equity concentration degree on the relationship between director networks centrality degree and cost of equity capital of non-state-owned listed companies.

The results show that the correlation coefficients between degree centrality and cost of equity and between betweenness centrality and cost of equity capital in the whole sample are 0.3171 and 0.0431 , respectively, and are positively correlated at the $1 \%$ level. Hypothesis 1 of this paper is confirmed again. The interaction term of equity concentration and degree centrality (Top $1 *$ Degree) and the interaction term of equity concentration and betweenness centrality (Top $1 *$ Betweenness) are significantly negatively correlated with the cost of equity capital. Equity concentration weakens the negative effect of director networks centrality on the cost of equity capital. Therefore, Hypothesis 3 of this paper is confirmed. The results demonstrate that a certain degree of equity concentration can alleviate the "free riding" behavior of minority shareholders and promote the major shareholders to have more motivation to supervise the interlocking directors because they enjoy absolute control rights. The relationship between director networks and cost of equity capital is influenced by equity concentration.

There is a significant negative correlation between the interaction term of equity concentration and degree centrality and cost of equity capital in state-owned listed companies. The interaction term of equity concentration and betweenness centrality has no significant negative correlation with the cost of equity capital. There is no significant negative correlation between the interaction term of equity concentration and degree centrality and the cost of equity capital and the interaction term of equity concentration and betweenness centrality and the cost of equity capital in the non-state-owned listed companies, and the coefficient of the cross-term of state-owned listed companies is higher than that of the non-state-owned listed companies. This result indicates that the equity concentration of state-owned listed companies has a more significant impact on the relationship between director networks and cost of equity capital.

4.6. Further Research. Wan and Zhang [40] divided directors into independent directors and nonindependent directors and studied the influence of different types of director networks connection on corporate mergers and acquisitions. Then will the network connection between independent directors and nonindependent directors are 


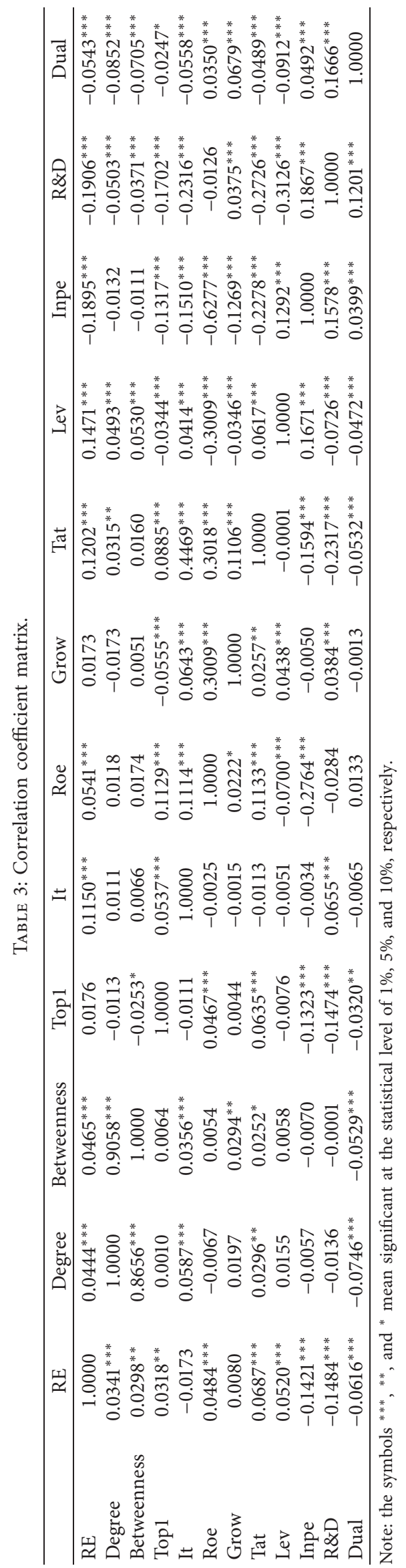


TABLE 4: Regression results: director networks and cost of equity capital.

\begin{tabular}{|c|c|c|c|c|c|c|}
\hline \multirow{2}{*}{ Variable } & \multicolumn{6}{|c|}{ All the samples } \\
\hline & (1) & (2) & (3) & (4) & (5) & (6) \\
\hline $\mathrm{C}$ & $\begin{array}{l}0.0887^{* * *} \\
(59.7473)\end{array}$ & $\begin{array}{l}0.0812^{* * *} \\
(42.0907)\end{array}$ & $0.1243^{* * *}(29.8283)$ & $\begin{array}{l}0.0904^{* * *} \\
(83.5070)\end{array}$ & $\begin{array}{l}0.0828^{* * *} \\
(50.1899)\end{array}$ & $0.1257^{* * *}(31.1019)$ \\
\hline Degree & $\begin{array}{c}0.1120^{* * * *} \\
(2.6234)\end{array}$ & $\begin{array}{c}0.1100^{* * *} \\
(2.5794)\end{array}$ & $0.0929^{* *}(2.2113)$ & & & \\
\hline Betweenness & & & & $0.0141^{* *}(2.2893)$ & $0.0135^{* *}(2.1915)$ & $0.0125^{* *}(2.0579)$ \\
\hline It & & $-0.0001(-1.4198)$ & $-0.0001(-0.9090)$ & & $-0.0001(-1.3473)$ & $-0.0001(-0.8517)$ \\
\hline Roe & & $0.0210^{* * *}(3.1701)$ & $0.0067(0.9952)$ & & $\begin{array}{c}0.0208^{* * *} \\
(3.1385)\end{array}$ & $0.0066(0.9708)$ \\
\hline Grow & & $0.0001(0.3667)$ & $0.0001(0.1801)$ & & $0.0001(0.3533)$ & $0.0001(0.1628)$ \\
\hline Tat & & $\begin{array}{c}0.0082^{* * *} \\
(4.7968)\end{array}$ & $0.0023(1.3325)$ & & $\begin{array}{c}0.0083^{* * *} \\
(4.8228)\end{array}$ & $0.0023(1.3416)$ \\
\hline Lev & & & $0.0017^{* * *}(4.8766)$ & & & $0.0017^{* * *}(4.8937)$ \\
\hline Inpe & & & $\begin{array}{c}-0.0080^{* * *} \\
(-9.2477)\end{array}$ & & & $-0.0080^{* * *}(-9.2477)$ \\
\hline $\mathrm{R} \& \mathrm{D}$ & & & $\begin{array}{r}-0.0056^{* * *} \\
(-8.4999)\end{array}$ & & & $-0.0016^{* * *}(-8.5222)$ \\
\hline Dual & & & $\begin{array}{c}-0.0056^{* * *} \\
(-2.8766)\end{array}$ & & & $-0.0057^{* * *}(-2.9310)$ \\
\hline$R^{2}$ & 0.0012 & 0.0078 & 0.0435 & 0.0009 & 0.0075 & 0.0434 \\
\hline $\mathrm{F}$ & 6.2284 & 9.2858 & 29.7638 & 5.2410 & 8.9131 & 29.6878 \\
\hline DW & 2.0096 & 2.0101 & 2.0178 & 2.0091 & 2.0095 & 2.0175 \\
\hline $\mathrm{N}$ & 5900 & 5900 & 5900 & 5900 & 5900 & 5900 \\
\hline
\end{tabular}

Note: the symbols ${ }^{* * *},{ }^{* *}$, and ${ }^{*}$ mean significant at the statistical level of $1 \%, 5 \%$, and $10 \%$, respectively. The bracket value is the $T$ value.

TABLE 5: Regression results: director networks, property right nature, and cost of equity capital.

\begin{tabular}{|c|c|c|c|c|c|c|c|c|}
\hline \multirow[b]{2}{*}{ Variable } & \multicolumn{8}{|c|}{ All the samples } \\
\hline & $\begin{array}{c}\text { State }=1 \\
(1)\end{array}$ & $\begin{array}{c}\text { State }=0 \\
(2)\end{array}$ & $\begin{array}{c}\text { State }=1 \\
(3)\end{array}$ & $\begin{array}{c}\text { State }=0 \\
(4)\end{array}$ & $\begin{array}{c}\text { State }=1 \\
(5)\end{array}$ & $\begin{array}{c}\text { State }=0 \\
(6)\end{array}$ & $\begin{array}{c}\text { State }=1 \\
(7)\end{array}$ & $\begin{array}{c}\text { State }=0 \\
(8)\end{array}$ \\
\hline $\mathrm{C}$ & $\begin{array}{c}0.1030^{* * *} \\
(34.4238)\end{array}$ & $\begin{array}{c}0.0833^{* * *} \\
(49.7955)\end{array}$ & $\begin{array}{l}0.1541^{* * *} \\
(21.3889)\end{array}$ & $\begin{array}{c}0.1126^{* * *} \\
(19.1382)\end{array}$ & $\begin{array}{l}0.1014^{* * *} \\
(46.8300)\end{array}$ & $\begin{array}{c}0.0856^{* * *} \\
(70.5361)\end{array}$ & $\begin{array}{l}0.1525^{* * *} \\
(22.0788)\end{array}$ & $\begin{array}{c}0.1150^{* * *} \\
(19.8391)\end{array}$ \\
\hline Degree & $\begin{array}{c}-0.0692 \\
(-0.9165)\end{array}$ & $\begin{array}{c}0.1544^{* * *} \\
(2.9567)\end{array}$ & $\begin{array}{c}-0.0780 \\
(-1.0645)\end{array}$ & $\begin{array}{c}0.1667^{* * *} \\
(3.2161)\end{array}$ & & & & \\
\hline Betweenness & & & & & $\begin{array}{c}-0.0056 \\
(-0.5202)\end{array}$ & $\begin{array}{c}0.01906^{* *} \\
(2.5071)\end{array}$ & $\begin{array}{c}-0.0079 \\
(-0.7625)\end{array}$ & $\begin{array}{c}0.0217^{* * *} \\
(2.8857)\end{array}$ \\
\hline It & & & $\begin{array}{c}0.0001 \\
(0.0110)\end{array}$ & $\begin{array}{l}-0.0001 \\
(-1.1825)\end{array}$ & & & $\begin{array}{c}0.0001 \\
(0.0208)\end{array}$ & $\begin{array}{l}-0.0001 \\
(-1.0673)\end{array}$ \\
\hline Roe & & & $\begin{array}{c}0.0125 \\
(1.5620)\end{array}$ & $\begin{array}{l}-0.0289^{*} \\
(-1.6777)\end{array}$ & & & $\begin{array}{c}0.0126 \\
(1.5784)\end{array}$ & $\begin{array}{l}-0.0293^{*} \\
(-1.7009)\end{array}$ \\
\hline Grow & & & $\begin{array}{c}-0.0001 \\
(-0.1148)\end{array}$ & $\begin{array}{c}0.0001 \\
(0.5378)\end{array}$ & & & $\begin{array}{c}-0.0001 \\
(-0.1218)\end{array}$ & $\begin{array}{c}0.0001 \\
(0.5135)\end{array}$ \\
\hline Tat & & & $\begin{array}{c}0.0007 \\
(0.2118)\end{array}$ & $\begin{array}{l}0.0040^{*} \\
(1.9201)\end{array}$ & & & $\begin{array}{c}0.0007 \\
(0.2262)\end{array}$ & $\begin{array}{c}0.0041^{* *} \\
(1.9715)\end{array}$ \\
\hline Lev & & & $\begin{array}{c}0.0028^{* * *} \\
(3.9056)\end{array}$ & $\begin{array}{c}0.0012^{* * *} \\
(2.9850)\end{array}$ & & & $\begin{array}{c}0.0028^{* * *} \\
(3.9032)\end{array}$ & $\begin{array}{c}0.0012^{* * *} \\
(3.0054)\end{array}$ \\
\hline Inpe & & & $\begin{array}{c}-0.0127^{* * *} \\
(-8.2825)\end{array}$ & $\begin{array}{c}-0.0060^{* * *} \\
(-5.1854)\end{array}$ & & & $\begin{array}{c}-0.0127^{* * *} \\
(-8.2868)\end{array}$ & $\begin{array}{c}-0.0060^{* * *} \\
(-5.1947)\end{array}$ \\
\hline $\mathrm{RD}$ & & & $\begin{array}{c}-0.0028^{* * *} \\
(-5.9895)\end{array}$ & $\begin{array}{c}-0.0012^{* * *} \\
(-5.9578)\end{array}$ & & & $\begin{array}{c}-0.0028^{* * *} \\
(-5.9761)\end{array}$ & $\begin{array}{c}-0.0012^{* * *} \\
(-5.9542)\end{array}$ \\
\hline Dual & & & $\begin{array}{c}-0.0015 \\
(-0.2683)\end{array}$ & $\begin{array}{l}-0.0040^{*} \\
(-1.9442)\end{array}$ & & & $\begin{array}{c}-0.0015 \\
(-0.2662)\end{array}$ & $\begin{array}{c}-0.0041^{* *} \\
(-2.0025)\end{array}$ \\
\hline Adj. $R^{2}$ & 0.0004 & 0.0022 & 0.0677 & 0.0297 & 0.0001 & 0.0016 & 0.0675 & 0.0292 \\
\hline $\mathrm{F}$ & 0.8400 & 8.7422 & 15.9336 & 13.2820 & 0.2706 & 6.2856 & 15.8679 & 13.0517 \\
\hline DW & 2.0459 & 1.8882 & 2.0186 & 1.8947 & 2.0462 & 1.8885 & 2.0194 & 1.8951 \\
\hline $\mathrm{N}$ & 1986 & 3916 & 1984 & 3916 & 1984 & 3916 & 1984 & 3916 \\
\hline
\end{tabular}

Note: the symbols ${ }^{* * *},{ }^{* *}$, and ${ }^{*}$ mean significant at the statistical level of $1 \%, 5 \%$, and $10 \%$, respectively. The bracket value is the $T$ value. 
TABLE 6: Regression results: director networks, equity concentration, and cost of equity capital.

\begin{tabular}{|c|c|c|c|c|c|c|}
\hline \multirow[t]{2}{*}{ Variable } & \multicolumn{2}{|c|}{ All the samples } & \multicolumn{2}{|c|}{$\begin{array}{c}\text { Samples of state-owned listed } \\
\text { companies }\end{array}$} & \multicolumn{2}{|c|}{$\begin{array}{c}\text { Samples of non-state-owned listed } \\
\text { companies }\end{array}$} \\
\hline & (1) & (2) & (3) & (4) & (5) & $(6)$ \\
\hline $\mathrm{C}$ & $\begin{array}{l}0.1191^{* * *} \\
(21.0757)\end{array}$ & $\begin{array}{l}0.1236^{* * *} \\
(24.7555)\end{array}$ & $\begin{array}{l}0.1367^{* * *} \\
(11.8697)\end{array}$ & $\begin{array}{l}0.1448^{* * *} \\
(14.7535)\end{array}$ & $\begin{array}{l}0.1161^{* * *} \\
(16.6141)\end{array}$ & $\begin{array}{l}0.1182^{* * *} \\
(18.5076)\end{array}$ \\
\hline Top1 & $0.0002(1.5197)$ & $0.0001(0.8596)$ & $0.0004^{* *}(2.0263)$ & $0.0002(1.1684)$ & $\begin{array}{l}-0.0001 \\
(-0.9249)\end{array}$ & $-0.0001(-1.1646)$ \\
\hline Degree & $\begin{array}{c}0.3171^{* * *} \\
(2.8424)\end{array}$ & & $0.4008^{*}(1.8095)$ & & $0.1950(1.4752)$ & \\
\hline Betweenness & & $\begin{array}{c}0.0431^{* * *} \\
(2.6629)\end{array}$ & & $0.0399(1.2026)$ & & $0.0360 *(1.9302)$ \\
\hline Top $1 *$ Degree & $\begin{array}{l}-0.0062^{* *} \\
(-2.1697)\end{array}$ & & $\begin{array}{l}-0.0116^{* *} \\
(-2.2894)\end{array}$ & & $\begin{array}{l}-0.0010 \\
(-0.2779)\end{array}$ & \\
\hline Top $1 *$ Betweenness & & $\begin{array}{l}-0.0008^{* *} \\
(-2.0405)\end{array}$ & & $-0.0011(-1.5172)$ & & $\begin{array}{l}-0.0004 \\
(-0.8732)\end{array}$ \\
\hline It & $\begin{array}{l}-0.0001 \\
(-0.9520)\end{array}$ & $\begin{array}{l}-0.0001 \\
(-0.8803)\end{array}$ & $\begin{array}{c}-0.0001 \\
(-0.0653)\end{array}$ & $\begin{array}{l}-0.0001 \\
(-0.0792)\end{array}$ & $-0.0001(-1.1777)$ & $-0.0001(-1.0700)$ \\
\hline Roe & $0.0071(1.0521)$ & $0.0068(1.0068)$ & $0.0138^{*}(1.7218)$ & $0.0132^{*}(1.6500)$ & $\begin{array}{l}-0.0252 \\
(-1.4572)\end{array}$ & $-0.0254(-1.4695)$ \\
\hline Grow & $0.0001(0.1674)$ & $0.0001(0.1548)$ & $-0.0001(-0.1527)$ & $-0.0001(-0.1417)$ & $0.0001(0.5548)$ & $0.0001(0.5352)$ \\
\hline Tat & $0.0023(1.2993)$ & $0.0023(1.2944)$ & $0.0010(0.3187)$ & $0.0010(0.3103)$ & $0.0040^{*}(1.9488)$ & $0.0040^{*}(1.9548)$ \\
\hline Lev & $\begin{array}{c}0.0017^{* * *} \\
(4.8788)\end{array}$ & $\begin{array}{c}0.0017^{* * *} \\
(4.9148)\end{array}$ & $\begin{array}{c}0.0028^{* * *} \\
(3.8680)\end{array}$ & $\begin{array}{l}0.0029^{* * *} \\
(3.9083)\end{array}$ & $\begin{array}{c}0.0012^{* * *} \\
(2.9573)\end{array}$ & $\begin{array}{c}0.0012^{* * *} \\
(2.9829)\end{array}$ \\
\hline Inpe & $\begin{array}{c}-0.0080^{* * *} \\
(-9.2415)\end{array}$ & $\begin{array}{c}-0.0081^{* * *} \\
(-9.2670)\end{array}$ & $\begin{array}{c}-0.0125^{* * *} \\
(-8.0697)\end{array}$ & $\begin{array}{c}-0.0127^{* * *} \\
(-8.1361)\end{array}$ & $\begin{array}{c}-0.0060^{* * *} \\
(-5.1877)\end{array}$ & $\begin{array}{c}-0.0060^{* * *} \\
(-5.2066)\end{array}$ \\
\hline $\mathrm{R} \& \mathrm{D}$ & $\begin{array}{c}-0.0016^{* * *} \\
(-8.5441)\end{array}$ & $\begin{array}{c}-0.0016^{* * *} \\
(-8.5601)\end{array}$ & $\begin{array}{c}-0.0028^{* * *} \\
(-5.9386)\end{array}$ & $\begin{array}{c}-0.0028^{* * *} \\
(-5.9045)\end{array}$ & $\begin{array}{c}-0.0012^{* * *} \\
(-6.1108)\end{array}$ & $\begin{array}{c}-0.0012^{* * *} \\
(-6.1355)\end{array}$ \\
\hline Dual & $\begin{array}{c}-0.0058^{* * *} \\
(-2.9739)\end{array}$ & $\begin{array}{c}-0.0058^{* * *} \\
(-3.0037)\end{array}$ & $\begin{array}{l}-0.0016 \\
(-0.2948)\end{array}$ & $\begin{array}{l}-0.0015 \\
(-0.2692)\end{array}$ & $\begin{array}{l}-0.0037^{*} \\
(-1.8059)\end{array}$ & $\begin{array}{l}-0.0039^{*} \\
(-1.8745)\end{array}$ \\
\hline$R^{2}$ & 0.0443 & 0.0441 & 0.0702 & 0.0686 & 0.0306 & 0.0303 \\
\hline $\mathrm{F}$ & 24.8029 & 24.6901 & 13.5414 & 13.2016 & 11.1956 & 11.0916 \\
\hline DW & 2.0192 & 2.0193 & 2.0215 & 2.0217 & 1.8969 & 1.8973 \\
\hline $\mathrm{N}$ & 5900 & 5900 & 1984 & 1984 & 3916 & 3916 \\
\hline
\end{tabular}

Note: the symbols ${ }^{* * *},{ }^{* *}$, and ${ }^{*}$ mean significant at the statistical level of $1 \%, 5 \%$, and $10 \%$, respectively. The bracket value is the $T$ value.

under a differentiated impact on the cost of equity capital of the company? First of all, all the company-director data from 2008 to 2018 can be obtained after manually identifying and removing the independent directors and nonindependent directors with the same name mentioned earlier. Second, this paper substitutes the company-independent director data and company-nonindependent director two-mode network matrix into Pajek software to transform it into a single-mode network matrix of independent directors formed by the same independent director serving in different companies and matrix of nonindependent directors formed by the same nonindependent director serving in different companies. UCINET 6.0 software is used to calculate the network centrality of independent directors and nonindependent directors. Table 7 tests the relationship between the networks centrality of independent directors and the cost of equity capital as well as the relationship between the networks centrality of nonindependent directors and the cost of equity capital.

After adding control variables, the regression coefficient between the centrality degree of independent director networks and the cost of equity capital is 0.0500 and significantly positive correlation at the $5 \%$ level. After adding control variables, the regression coefficient between the centrality degree of nonindependent directors network and the cost of equity capital is 0.1074 , and there is a significant positive correlation at the $10 \%$ level. The regression coefficient between the betweenness centrality of the independent director networks without control variables, and the cost of equity capital is 0.0083 and significantly positively correlated at the level of $5 \%$. The regression coefficient between the betweenness centrality of the nonindependent director networks without control variables, and the cost of equity capital is 0.0097 and significantly positive at the level of $10 \%$. It can be observed that the regression coefficient of network centrality of nonindependent directors on cost of equity capital is greater than that of network centrality of independent directors on cost of equity capital. The negative effect of director networks centrality on the cost of equity capital is mainly caused by nonindependent directors. This paper believes that the reason for this result is that independent directors will be mindful of the increase of their own responsibilities when accepting additional appointments and will be cautious about the appointments of other companies. The concurrent role of independent director has stronger supervisory function than that of nonindependent director. This paper further verifies the quality hypothesis. 
TABLE 7: Regression results: director networks type and cost of equity capital.

\begin{tabular}{|c|c|c|c|c|c|c|c|c|}
\hline \multirow{2}{*}{ Variable } & \multicolumn{4}{|c|}{ Network of independent directors } & \multicolumn{4}{|c|}{ Network of nonindependent directors } \\
\hline & (1) & (2) & (3) & (4) & (5) & (6) & (7) & (8) \\
\hline $\mathrm{C}$ & $\begin{array}{l}0.0897^{* * *} \\
(63.5797)\end{array}$ & $\begin{array}{l}0.1120^{* * *} \\
(28.8999)\end{array}$ & $\begin{array}{l}0.0905^{* * *} \\
(85.3185)\end{array}$ & $\begin{array}{l}0.1205^{* * *} \\
(29.3961)\end{array}$ & $\begin{array}{l}0.0904^{* * * *} \\
(83.3831)\end{array}$ & $\begin{array}{l}0.1205^{* * *} \\
(29.3052)\end{array}$ & $\begin{array}{l}0.0914^{* * *} \\
(98.5829)\end{array}$ & $\begin{array}{l}0.1212^{* * *} \\
(29.8469)\end{array}$ \\
\hline Degree & $\begin{array}{c}0.0533^{* *} \\
(2.1596)\end{array}$ & $\begin{array}{c}0.0500^{* *} \\
(2.0500)\end{array}$ & & & $\begin{array}{c}0.1492^{* *} \\
(2.5591)\end{array}$ & $\begin{array}{l}0.1074^{*} \\
(1.8612)\end{array}$ & & \\
\hline Betweenness & & & $\begin{array}{c}0.0112^{* * *} \\
(2.6729)\end{array}$ & $\begin{array}{l}0.0083^{* *} \\
(2.0004)\end{array}$ & & & $\begin{array}{l}0.0124^{* *} \\
(2.6729)\end{array}$ & $\begin{array}{l}0.0097^{*} \\
(1.7531)\end{array}$ \\
\hline It & & $\begin{array}{c}0.0001 \\
(1.2125)\end{array}$ & & $\begin{array}{c}0.0001 \\
(1.2144)\end{array}$ & & $\begin{array}{c}0.0001 \\
(1.2306)\end{array}$ & & $\begin{array}{c}0.0001 \\
(1.2249)\end{array}$ \\
\hline Roe & & $\begin{array}{c}0.0024 \\
(0.3491)\end{array}$ & & $\begin{array}{c}0.0025 \\
(0.3628)\end{array}$ & & $\begin{array}{c}0.0029 \\
(0.4184)\end{array}$ & & $\begin{array}{c}0.0025 \\
(0.3858)\end{array}$ \\
\hline Grow & & $\begin{array}{l}-0.0001 \\
(-0.0641)\end{array}$ & & $\begin{array}{c}-0.0001 \\
(-0.0851)\end{array}$ & & $\begin{array}{l}-0.0001 \\
(-0.1193)\end{array}$ & & $\begin{array}{l}-0.0001 \\
(-0.1410)\end{array}$ \\
\hline Tat & & $\begin{array}{c}0.0048^{* * *} \\
(2.6375)\end{array}$ & & $\begin{array}{c}0.0049^{* * *} \\
(2.6872)\end{array}$ & & $\begin{array}{c}0.0049^{* * *} \\
(2.6743)\end{array}$ & & $\begin{array}{c}0.0050^{* * *} \\
(2.7180)\end{array}$ \\
\hline Lev & & $\begin{array}{c}0.0020^{* * *} \\
(5.3632)\end{array}$ & & $\begin{array}{c}0.0019^{* * *} \\
(5.3627)\end{array}$ & & $\begin{array}{c}0.0019^{* * *} \\
(5.3659)\end{array}$ & & $\begin{array}{c}0.0019^{* * *} \\
(5.3548)\end{array}$ \\
\hline Inpe & & $\begin{array}{c}-0.0090^{* * *} \\
(-10.3391)\end{array}$ & & $\begin{array}{c}-0.0089^{* * *} \\
(-10.2152)\end{array}$ & & $\begin{array}{c}-0.0089^{* * *} \\
(-10.2183)\end{array}$ & & $\begin{array}{c}-0.0089^{* * *} \\
(-10.2382)\end{array}$ \\
\hline Dual & & $\begin{array}{c}-0.0074^{* * *} \\
(-3.7582)\end{array}$ & & $\begin{array}{c}-0.0074^{* * *} \\
(-3.7675)\end{array}$ & & $\begin{array}{c}-0.0073^{* * *} \\
(-3.7267)\end{array}$ & & $\begin{array}{c}-0.0074^{* * *} \\
(-3.7829)\end{array}$ \\
\hline $\operatorname{Adj} . R^{2}$ & 0.0008 & 0.0303 & 0.0012 & 0.0303 & 0.0011 & 0.0302 & 0.0012 & 0.0301 \\
\hline $\mathrm{F}$ & 4.6640 & 22.8607 & 7.1444 & 22.8348 & 6.5492 & 22.7656 & 7.1444 & 22.7153 \\
\hline DW & 1.8778 & 1.8941 & 1.8783 & 1.8937 & 1.8842 & 1.8995 & 1.8783 & 1.9002 \\
\hline $\mathrm{N}$ & 5861 & 5861 & 5861 & 5861 & 5861 & 5861 & 5861 & 5861 \\
\hline
\end{tabular}

Note: the symbols ${ }^{* * *},{ }^{* *}$, and ${ }^{*}$ mean significant at the statistical level of $1 \%, 5 \%$, and $10 \%$, respectively. The bracket value is the $T$ value.

TABLE 8: Robustness test.

\begin{tabular}{|c|c|c|c|c|c|}
\hline Variable & $\begin{array}{l}\text { Changing the } \\
\text { measurement of network } \\
\text { centrality }\end{array}$ & $\begin{array}{l}\text { Changing the } \\
\text { sample size }\end{array}$ & $\begin{array}{l}\text { Changing the } \\
\text { sample size }\end{array}$ & $\begin{array}{l}\text { Excluding the samples whose } \\
\text { "director network centrality" } \\
\text { is } 0\end{array}$ & $\begin{array}{c}\text { Excluding the samples whose } \\
\text { "director network centrality" } \\
\text { is } 0\end{array}$ \\
\hline Degree & & $\begin{array}{c}0.0906^{* *} \\
(2.13)\end{array}$ & & $\begin{array}{c}0.8733^{*} \\
(1.89)\end{array}$ & \\
\hline Betweenness & & & $\begin{array}{c}0.0113^{*} \\
(1.78)\end{array}$ & & $\begin{array}{c}0.0108^{*} \\
(1.70)\end{array}$ \\
\hline Closeness & $\begin{array}{c}0.0043^{*} \\
(1.80)\end{array}$ & & & & \\
\hline _Cons & $\begin{array}{c}0.1216^{* * *} \\
(22.23)\end{array}$ & $\begin{array}{c}0.1251^{* * *} \\
(25.59)\end{array}$ & $\begin{array}{c}0.1265^{* * *} \\
(26.45)\end{array}$ & $\begin{array}{c}0.1244^{* * *} \\
(23.67)\end{array}$ & $\begin{array}{c}0.1259^{* * *} \\
(24.62)\end{array}$ \\
\hline Controls & Yes & Yes & Yes & Yes & Yes \\
\hline Year & Yes & Yes & Yes & Yes & Yes \\
\hline $\mathrm{N}$ & 5900 & 5732 & 5732 & 5180 & 5180 \\
\hline$r^{2}$ & 0.0418 & 0.0433 & 0.0431 & 0.0424 & 0.0423 \\
\hline
\end{tabular}

Note: the symbols ${ }^{* * *},{ }^{* *}$, and ${ }^{*}$ mean significant at the statistical level of $1 \%, 5 \%$, and $10 \%$, respectively. The bracket value is the $T$ value.

\section{Robustness Test}

To make the research conclusion more reliable, the following robustness tests are made in this paper: (1) this paper uses proximity centrality (closeness) to re-measure the director network. Regression analysis is conducted on the sample data of A-share-listed companies in Shanghai and Shenzhen Stock Exchange from 2008 to 2018. The conclusion obtained is consistent with the results in Tables 4 and 5, and the significance level does not change. The research conclusion of this paper has strong robustness. (2) This paper selects data from 2010 to 2018 as samples to repeat the aforementioned empirical research process and obtains results consistent with the coefficient symbols in Tables 4 and 5 without any change in significance level. The research conclusion of this paper has strong robustness. (3) In this paper, samples with zero "director networks centrality" were eliminated and the regression analysis was carried out again on the collated data, and the regression results were basically consistent with the previous conclusions. This paper proves that the aforementioned research conclusions are robust. Table 8 is the result of the robustness test. 


\section{Research Conclusion and Recommendations}

6.1. Research Conclusion. Based on the samples of China's A-share-listed companies in Shanghai and Shenzhen Stock Exchange from 2008 to 2018, this paper studies the influence of director networks centrality on the cost of equity capital and discusses the influence of director networks centrality on the cost of equity capital under different property right nature and equity concentration degree. The results show the following: First, director networks centrality has a significant positive correlation with cost of equity capital. Director networks centrality of listed companies have a negative impact on the cost of equity capital. The cost of equity capital of listed companies increases with the increase of the director networks centrality. This paper holds that the enthusiasm of interlocking directors' supervision will decrease with the increase of the number of companies in which interlocking directors hold positions. The phenomenon is not conducive to the improvement of financing efficiency. Second, compared with state-owned listed companies, the cost of equity capital of non-state-owned listed companies increases more significantly with the enhancement of director networks centrality. Third, equity concentration can restrain the relationship between director networks centrality and cost of equity capital. It can be observed that the ownership structure of an enterprise can indeed have an impact on the governance of directors. Under the condition of different equity concentration, the performance of concurrent directors is significantly different and this difference is reflected in the inconsistent supervisory role. Fourth, independent directors are accompanied by intense supervision function. The negative effect of network centrality of nonindependent directors on the cost of equity capital is stronger than that of independent directors.

6.2. Recommendations. First, standardize the director networks and appropriately restrict concurrent activities among directors. At present, under the condition that China's corporate governance system is not perfect, the concurrent behavior of corporate directors may adversely affect the operational efficiency and quality of corporate governance and then affect the financing efficiency. All institutions should properly restrain and standardize the concurrent behavior of enterprise directors. First of all, listed companies should avoid or moderately reduce the phenomenon of busy directors caused by the concurrent behavior of directors and improve the participation of directors in the process of corporate governance. In the process of appointing a director, it is necessary to know clearly whether the director works in other companies at the same time to ensure that no more than five companies. Strengthen the punishment of illegal regulations to ensure that interlocking directors keep adequate time and energy to better play their roles and perform their functions. Second, listed companies should formulate and implement appropriate systems to motivate directors and improve the enthusiasm of interlocking directors to participate in enterprise supervision. Enterprises should encourage directors to establish relationships with companies that can provide effective information and scarce resources for the company, so as to make up for the adverse effects caused by the phenomenon of busy directors. Third, the corresponding government departments should also properly restrain the concurrent behavior among directors and effectively guide the constructive role of the director networks in enterprises. Sound macro-institutional environment and the formulation and implementation of laws and regulations related to chain directors are very important to regulate the behavior of chain directors. The government can introduce policies and regulations to limit the number, industries, and regions of enterprises where directors concurrently hold positions and further improve the legal, financial, and credit systems. The local government should introduce regulatory policies in combination with the inconsistent financial and legal levels in various places.

Second, optimize the shareholding structure and appropriately increase the shareholding ratio of the largest shareholder. Divide into two parts to treat the phenomenon of equity concentration. Equity concentration in enterprises is a very widespread phenomenon and is often regarded as a "bad thing." This has a negative impact on corporate governance, and then becomes a scapegoat for many enterprise problems. However, in this study, it is found that large shareholders with higher shareholding ratio can form a more positive supervision effect on busy directors. Therefore, enterprises should further optimize the ownership structure and appropriately increase the shareholding ratio of the largest shareholder to give full play to the supervisory role of enterprise shareholders, improve the efficiency of capital allocation, and reduce the opportunism of concurrently serving as directors. Under the effective constraint and supervision environment, enterprises can give full play to the supervisory function of directors, thus improving the efficiency of corporate governance, further enhancing the vitality, efficiency and competitiveness of enterprises, and finally promoting the development of enterprises.

Third, increase the proportion of independent directors and give full play to the supervisory role of independent directors. When accepting additional appointments, independent directors will be aware of the increase of their personal responsibilities and treat the appointments of other companies with caution. Independent directors have a stronger supervisory function than nonindependent directors. Therefore, enterprises can appropriately increase the proportion of independent directors in the board structure. In the process of appointing directors, enterprises should employ interlocking independent directors with high reputation according to their own needs, industry, region, enterprise life cycle, ownership structure and management composition, and strengthen the assessment of institutionalization process according to the functional requirements of interlocking independent directors. Enterprises should give full play to the supervision function of independent directors on corporate governance behavior and enhance their ability to supervise management and safeguard the interests of stakeholders, so as to better serve enterprises and enhance the corporate governance level of enterprises. 


\section{Data Availability}

The data used to support the findings of this study are available from the corresponding author upon request.

\section{Conflicts of Interest}

The authors declare that they have no conflicts of interest.

\section{Acknowledgments}

The authors thank Dr. Zhibin Zhang (Shandong University of Finance and Economics, China) for his devoted work and data processing of this study.

\section{References}

[1] P. Andrsa and J. A. Rodrguez, "Corporate boards in high-tech firms," The Spanish Review of Financial Economics, vol. 9, no. 2, pp. 69-79, 2011.

[2] J. Zhou, S. H. Wang, and S. P. Zhang, "Information provision of secretaries, performance effectiveness of independent directors and corporate performance," Management Science, vol. 31, no. 5, pp. 97-116, 2018.

[3] I. Boulouta, "Hidden connections: the link between board gender diversity and corporate social performance," Journal of Business Ethics, vol. 113, no. 2, pp. 185-197, 2013.

[4] Y. Deutsch, T. Keil, and T. Laamanen, "A dual agency view of board compensation: the joint effects of outside director and CEO stock options on firm risk," Strategic Management Journal, vol. 32, no. 2, pp. 212-227, 2011.

[5] A. B. Brown, J. Dai, and E. Zur, "Too busy or well-connected? evidence from a shock to multiple directorships," The Accounting Review, vol. 94, no. 2, pp. 83-104, 2019.

[6] P. A. Bianchi, M. Causholli, and M. Minutti-Meza, Social Networks Analysis in Accounting and Finance, University of Miami Business School, Coral Gables, FL, USA, 2019.

[7] A. B. Matthies, Empirical Research on Corporate CreditRatings: A Literature Review, SFB 649, Humboldt-Universität zu Berlin, Germany, 2013.

[8] D. H. Tran, "Multiple corporate governance attributes and the cost of capital-evidence from Germany," The British Accounting Review, vol. 46, no. 2, pp. 179-197, 2014.

[9] K. C. W. Chen, Z. Chen, and K. C. J. Wei, "Agency costs of free cash flow and the effect of shareholder rights on the implied cost of equity capital," Journal of Financial and Quantitative Analysis, vol. 46, no. 1, pp. 171-207, 2011.

[10] P. K. Pham, J. A. Suchard, and J. Zein, "Corporate governance and the cost of capital: evidence from Australian companies," The Journal of Applied Corporate Finance, vol. 28, no. 1, pp. 84-93, 2012.

[11] E. A. Abdul Wahab, M. F. Jamaludin, D. Agustia, and I. Harymawan, "Director networks, political connections, and earnings quality in Malaysia," Management and Organization Review, vol. 16, no. 3, pp. 687-724, 2020.

[12] Y. Feng, K. Song, and Y. S. Tian, "Director networks and initial public offerings," Journal of Banking \& Finance, vol. 106, no. 9, pp. 246-264, 2019.

[13] B. Ren, K. Y. Au, and T. A. Birtch, "China's business network structure during institutional transitions," Asia Pacific Journal of Management, vol. 26, no. 2, pp. 219-240, 2009.

[14] D. F. Larcker, E. So, and C. C. Wang, "Boardroom centrality and firm performance," Journal of Accounting and Economics, vol. 55, no. 3, pp. 225-250, 2013.
[15] X. Fang, J. Pittman, and Y. Zhao, "The importance of director external social networks to stock price crash risk," Contemporary Accounting Research, vol. 23, pp. 1-39, 2021.

[16] D. Li, Q. Jiang, and Y. Mai, "Board interlocks and capital structure dynamics: evidence from China," Accounting and Finance, vol. 59, no. 2, pp. 1893-1922, 2019.

[17] J. Han, N. Hu, L. Liu, and G. Tian, "Does director interlock impact the diffusion of accounting method choice?" Journal of Accounting and Public Policy, vol. 36, no. 4, pp. 316-334, 2017.

[18] L. Shao, C. B. Han, and F. Y. Chen, "Research on the influence of economic policy uncertainty on enterprise investment based on director networks," China Soft Science, vol. 5, pp. 184-192, 2020.

[19] H. H. Huang, C. Wang, and H. Xie, "Independent director attention and the cost of equity capital," Social Science Electronic Publishing, vol. 10, pp. 1-26, 2021.

[20] K. Barhava, G. Feng, and B. Lev, "Market evidence on investor preference for fewer directorships," Journal of Financial and Quantitative Analysis, vol. 55, no. 3, pp. 931-954, 2020.

[21] R. W. Masulis and E. J. Zhang, "How valuable are independent directors? evidence from external distractions," Journal of Financial Economics, vol. 132, no. 3, pp. 226-256, 2019.

[22] S. P. Ferris, M. Jagannathan, and A. C. Pritchard, "Too busy to mind the business? monitoring by directors with multiple board appointments," The Journal of Finance, vol. 58, no. 3, pp. 1087-1111, 2003.

[23] E. M. Fich and A. Shivdasani, "Are busy boards effective monitors?" The Journal of Finance, vol. 109, no. 1, pp. 689-724, 2006.

[24] C. Y. Hsu and C. A. Li, "Stock price reaction to voluntary announcements of independent director appointments: effect of multiple directorships from Taiwan," International Research Journal of Finance and Economics, vol. 33, pp. 101-110, 2009.

[25] R. L. Santos and A. M. Silveira, "Board interlocking in Brazil: directors' participation in multiple companies and its effect on firm value and profitability," Latin American Business Review, vol. 13, no. 1, pp. 1-28, 2012.

[26] M. Non and P. H. Franses, Interlocking Boards and Firm Performance: Evidence from a New Panel Database, Tinbergen Institute, Amsterdam, Netherlands, 2007.

[27] Y. Jiang and Z. F. Lu, "Corporate governance and equity financing costs-study on the governance effects of single and comprehensive mechanisms," Quantitative Economics and Technical Economics, vol. 26, no. 2, pp. 60-75, 2009.

[28] A. Alhares, "Corporate governance and cost of capital in OECD countries," International Journal of Accounting and Information Management, vol. 28, no. 1, pp. 1-21, 2020.

[29] M. R. Iskander and N. Chamlou, Corporate Governance:a Framework for Implementation, The World Bank, Washington, DC, USA, 2000.

[30] C. S. A. Cheng, D. Collins, and H. H. Huang, "Shareholder rights, financial disclosure and the cost of equity capital," Review of Quantitative Finance and Accounting, vol. 27, no. 2, pp. 175-204, 2006.

[31] Y. X. Wu, J. J. Shi, and X. S. Cheng, "Board social capital and enterprise risk-based on the empirical evidence of listed manufacturing enterprises in China," East China Economic Management, vol. 33, no. 5, pp. 116-122, 2019.

[32] H. Wei, X. Yang, and H. Wu, "Governance environment, separation of the two powers of the ultimate controller and the cost of equity financing," Southern Economist, vol. 12, pp. 3-15, 2011. 
[33] D. K. Denis and J. J. Mcconnell, "International corporate governance," Journal of Financial and Quantitative Analysis, vol. 38, no. 1, pp. 1-36, 2003.

[34] T. Baldenius, N. Melumad, and X. Meng, "Board composition and CEO power," Journal of Financial Economics, vol. 112, no. 1, pp. 53-68, 2014.

[35] C. B. Zhou, "Investment strategy, governance mechanism and financing cost of tourism enterprises," Journal of Tourism Science, vol. 29, no. 8, pp. 50-61, 2014.

[36] X. J. Lv, "Ownership structure, executive incentive and governance efficiency of listed companies-research based on heterogeneous stochastic boundary model," Management Review, vol. 27, no. 6, pp. 128-139, 2015.

[37] P. D. Easton, "PE ratios, PEG ratios, and estimating the implied expected rate of return on equity capital," The Accounting Review, vol. 79, no. 1, pp. 73-95, 2004.

[38] L. C. Freeman, "Centrality in social networks: conceptual clarification," Social Networks, vol. 1, no. 3, pp. 215-239, 1979.

[39] X. P. Zhang, X. Y. Li, and C. Liu, "Does asset quality affect the cost of equity?" Accounting Research, vol. 2, pp. 43-59, 2020.

[40] L. Y. Wan and X. L. Zheng, "Structural hole characteristics of director networks and corporate mergers and acquisitions," Accounting Research, vol. 5, no. 2, pp. 72-95, 2014. 